\title{
An investigation of incompatible trace elements in Massif Central mantle xenoliths by laser ablation ICP-MS: a new tool for investigating mantle geochemistry
}

\author{
Mason, P.R.D. ${ }^{1,3}$, Downes, H. ${ }^{2}$, Jarvis $\mathrm{K}^{3}$ and Vannucci, ${ }^{4}$
}

1. Institute of Earth Sciences, University of Utrecht, P.O. Box 80021, 3508 TA, Utrecht, Netherlands.

2. Department of Geology, Birkbeck College, Malet St, London WC1E 7HX, U.K.

3. NERC ICP-MS Facility, ICCET., Imperial College, Silwood Park, Ascot, Berks, SL5 7TE, U.K.

4. C.N.R. Centro di Studio per la Cristallochimica e la Cristallografia, Via Ferrata, 1, I-27100, Pavia, Italy

Laser ablation inductively coupled plasma mass spectrometry (LA-ICP-MS) can be a powerful technique for the relatively accurate and precise in-situ analysis of trace elements in mantle phases down to very low concentrations $\left(<100 \mathrm{ngg}^{-1}\right.$ to $1 \mu \mathrm{gg}^{-1}$, depending on mass). We have determined concentrations of incompatible trace elements in separated clinopyroxene grains from mantle xenoliths from the Massif Central, previously analysed by various analytical techniques by Downes and Dupuy (1987), Vannucci et al. (1994), Zangana et al. (1997) with additional unpublished data.

To achieve optimum data quality during the analysis of these relatively homogeneous minerals, sampling has generally been carried out by rastering the laser beam over an area of approximately 100 by $150 \mu \mathrm{m}$ on the sample substrate. Where minerals were too small for this procedure, a spot method was employed, with a corresponding degradation of precision. The long-term reproducibility of the technique for most elements is shown by the consistency of results for one sample of clinopyroxene analysed on 13 occasions over a period of 9 months. Calibration was carried out using an internal standard element (in this case $\mathrm{Ca}$ determined by electron microprobe) and external standardisation was performed against NIST glass (NIST 612).

Mean results for $\mathrm{REE}, \mathrm{Sr}, \mathrm{Y}$ and $\mathrm{Zr}$ in agree closely previously determined values by SIMS and isotope dilution mass spectrometry techniques (ID-TIMS; ID-ICP-MS). The LA-ICP-MS technique can also determine $\mathrm{Ta}, \mathrm{Nb}, \mathrm{Hf}, \mathrm{U}, \mathrm{Th}$ and $\mathrm{Pb}$ at sub-ppm levels and for most of these elements agreement of our new data with that determined by other methods is also good. However, the chalcophile elemetn $\mathrm{Pb}$ behaves errativally during ablation and calibration with the lithophile $\mathrm{Ca}$ internal standard was of limited success, confirming the observations of previous studies (e.g. Longerich et al., 1996). Rb and Ba 
were below detection limits except in a few instances where fluid inclusions may have been present.

The samples analysed are mostly anhydrous four-phase spinel lherzolites, but two harzburgites and one pyroxenite are also in our sample set. A wide range of textural types ranging from protogranular to poikilitic is also represented. LREE-depleted and LREEenriched xenolith types were also included. The ranges of trace element concentrations in mantle clinopyroxenes determined by LA-ICP-MS are very wide, in some cases exceeding an order of magnitude, e.g. 24-355ppm Sr, 3-34ppm Y, <0.08-1.5ppm Nb, confirming results determined by other techniques. In clinopyroxenes from the pyroxenite, some elements are particularly enriched (e.g. in the peridotites, Hf ranges from 0.17-1.3ppm, but reaches $7.5 \mathrm{ppm}$ in the pyroxenite; likewise $\mathrm{Zr}$ ranges from $9-41 \mathrm{ppm}$ in peridotites but is $243 \mathrm{ppm}$ in the pyroxenite).

Among LREE-depleted xenoliths, most of the most strongly incompatible elements (U, $\mathrm{Th}, \mathrm{Ta}, \mathrm{Nb}$ ) are below the detection limits of the technique (20-80 ppb). Sr, Zr, Hf and Y have similar mantle-normalised abundances to the REE, forming smooth mantlenormalised trace element patterns, using the coefficients of Sun and McDonough (1989). $\mathrm{Pb}$ often forms small positive or negative anomalies with respect to adjacent elements in mantle-normalised diagrams, but this may be due to the high analytical uncertainty of the $\mathrm{Pb}$ determinations and may not be petrogenetically significant. Overall, the new data confirm that the LREE-depleted xenoliths have undergone a relatively simple history of melt extraction without any subsequent addition of incompatible elements (Zangana et al., 1997).

Among the LREE-enriched xenoliths, $U$ and Th concentrations are variable and are often more enriched in clinopyroxene than other elements of similar incompatibility. This is considered to be a genuine feature of the enriched samples, indicating that metasomatism strongly enhances the abundances of $U$ and $\mathrm{Th}$ in the mantle. $\mathrm{Sr}, \mathrm{Zr}, \mathrm{Hf}$ and $\mathrm{Y}$ again usually form smooth patterns with adjacent elements in mantle-normalised diagrams, although $\mathrm{Zr}$ and $\mathrm{Hf}$ are conspicuously depleted in the clinopyroxenes from LREE-enriched harzburgites, and in some enriched clinopyroxenes $\mathrm{Sr}$ forms a strong positive anomaly. In clinopyroxenes from most of the LREE-enriched xenoliths, $\mathrm{Nb}$ and $\mathrm{Ta}$ are strongly depleted relative to adjacent elements (U, Th, LREE). This confirms the observations of Bodinier et al. (1996) and Ionov et al. (1995) that $\mathrm{Nb}$ and $\mathrm{Ta}$ are not partitioned into mantle pyroxenes but must be housed by another phase, e.g. spinel. 
Our analyses confirm that the LA-ICP-MS technique, when used under carefully controlled conditions, can reproduce REE patterns and incompatible element concentrations to high degrees of accuracy and precision in relatively homogeneous mantle clinopyroxenes. As the laser probe can spatially resolve the analysis of minerals in $>80$ micron thick sections, we consider that LA-ICP-MS will add another important tool to the study of trace element abundances in mantle materials.

\section{References}

Bodinier, J.-L., Merlet, C., Bedini, R.M., Simien, F., Remaidi, M. and Garrido, C.J., 1996. Distribution of niobium, tantalum, and other highly incompatible trace elements in the lithospheric mantle: The spinel paradox. Geochim. Cosmochim. Acta, 60, 545-550.

Downes, H. and Dupuy, C., 1987, Textural, isotopic and REE variations in spinel peridotite xenoliths, Massif Central, France. Earth Planet. Sci. Lett. 82, p 121-135.

Ionov, D.A., Prikhod'co, V.S. and O'Reilly, S. Y., 1995. Peridotite xenoliths in alkali basalts from the Sikhote-Alin, southeastern Siberia, Russia: trace element signatues of mantle beneath a convergent continental margin. Chem. Geol. 120, 275-294.

Longerich, H.P., Gunther, D. and Jackson, S.E., 1996. Elemental fractionation in laser ablation inductively coupled plasma mass spectrometry. Fres. J. Anal. Chem., 355: 538542 .

Sun, S.-S. and McDonough, W. F. 1989. Chemical and isotopic systematics of oceanic basalts: implications for mantle composition and processes. In: Magmatism in the Ocean Basins. (Eds. Saunders, A. D. and Norry, M. J.). Geol. Soc. Sp. Pub. 42, 313-345.

Vannucci, R., Ottolini, L., Bottazzi, P., Downes, H. and Dupuy, C., 1994, INAA, IDMS and SIMS comparative REE investigations of clinopyroxenes from mantle xenoliths with different textures. Chem. Geol. 118, 85-108.

Zangana, N. A., Downes, H., Thirlwall, M. F. and Hegner, E., 1997, Relationship between deformation, equilibration temperatures, REE and radiogenic isotopes in mantle xenoliths (Ray Pic, Massif Central, France): an example of plume-lithosphere interaction? Contrib. Mineral. Petrol. 127, 187-203. 